\title{
Kajian Berbagai Pola Tanam terhadap Peningkatan Produktivitas Jagung dan Kedelai dengan Berbagai Varietas Jagung
}

\section{Study of Various Planting Patterns on Increasing the Productivity of Maize and Soybeans with Various Maize Varieties}

\author{
Siti Hapita Sari ${ }^{1}$, Munif Ghulamahdi ${ }^{2}$, Willy Bayuardi Suwarno ${ }^{2}$, dan Maya Melati ${ }^{2}$ \\ 'Program Studi Agronomi dan Hortikultura, Sekolah Pascasarjana, Institut Pertanian Bogor \\ ${ }^{2}$ Departemen Agronomi dan Hortikultura, Fakultas Pertanian, Institut Pertanian Bogor \\ (IPB University), Jl. Meranti, Kampus IPB Darmaga, Bogor 16680, Indonesia
}

Diterima 25 Agustus 2020/Disetujui 2 Desember 2020

\begin{abstract}
The reduction in agricultural land due to land conversion has encouraged several technological innovations in cultivation systems, including intercropping planting patterns. Thestudyaimed to studyintercropping patterns of severalmaize varieties with soybean, and the relationship among microclimate (due to cropping patterns) and productivity. The research was conducted at the Sawah Baru Experimental Station of the IPB University, Darmaga, Bogor, from November 2018 to February 2019 using a splitplot design with three replications. The main plot was the cropping systems, consisting of monoculture, single-rowintercropping, double-rows intercropping, and triple-rows intercropping. The subplot was the maize varieties, consisting of Sukmaraga, Bima 19, and BISI 2. Regression and correlation analyses were carried out to determine the relationship between microclimate and productivity. The results showed that the productivity of maize and soybean was affected by the interaction between cropping patterns and varieties. The highest productivity of maize was obtained from the intercropping pattern of double rows of BISI 2 maize (7.33 ton $\mathrm{ha}^{-1}$ ), while the lowest maize productivity was in the intercropping pattern of a single row of Bima 19 maize (2.93 ton $\mathrm{ha}^{-1}$ ). The highest productivity of soybean was obtained from the intercropping cropping pattern of a single row of BISI 2 maize. The effect of microclimate on various cropping patterns with productivity in this study was a little. Land equivalent ratios (LER) in all treatments were greater than 1 except for intercropping 1 row of Bima 19 maize, indicating that intercropping can increase land productivity.
\end{abstract}

Keywords: cropping pattern, intercropping, land equivalent ratio (LER), maize varieties

\section{ABSTRAK}

Berkurangnya lahan pertanian dikarenakan alih fungsi lahan mendorong beberapa inovasi teknologi sistem budidaya termasuk pola tanam tumpangsari. Penelitian ini bertujuan mempelajari pola tanam tumpangsari beberapa varietas jagung dengan kedelai, serta hubungan antara iklim mikro (akibat pola tanam) dan produktivitas. Penelitian dilakukan di Kebun Percobaan Sawah Baru IPB, Darmaga, Bogor, dari November 2018 hingga Februari 2019, menggunakan rancangan petak terbagi dengan tiga ulangan. Petak utama yaitu pola tanam yang terdiri atas monokultur, tumpangsari baris tunggal, tumpangsari baris ganda, dan tumpangsari tiga baris. Anak petak yaitu varietas jagung yang terdiri atas Sukmaraga, Bima 19, dan BISI 2. Analisis korelasi dan regresi untuk mengetahui hubungan antara iklim mikro dan produktivitas. Hasil penelitian menunjukkan produktivitas tanaman jagung dan kedelai dipengaruhi oleh interaksi antar pola tanam dan varietas. Pada tanaman jagung produktivitas tertinggi terdapat pada pola tanam tumpangsari 2 baris jagung BISI 2 (7.33 ton ha-1), sedangkan produktivitas jagung terendah pada pola tanam tumpangsari 1 baris jagung Bima 19 (2.93 ton ha ${ }^{-1}$ ). Produktivitas kedelai tertinggi terdapat pada pola tanam tumpangsari 1 baris jagung BISI 2. Pengaruh iklim mikro pada berbagai pola tanam dengan produktivitas pada penelitian sangat kecil. Nisbah kesetaraan lahan (NKL) pada semua perlakuan lebih dari 1 kecuali pada tumpangsari 1 baris jagung Bima 19, mengindikasikan bahwa pola tumpangsari dapat meningkatkan produktivitas lahan. .

Kata kunci: nisbah kesetaraan lahan (NKL), pola tanam, tumpangsari, varietas jagung

\footnotetext{
* Penulis untuk korespondensi. e-mail: mghulamahdi@yahoo.com
} 


\section{PENDAHULUAN}

Jagung merupakan salah satu komoditi terpenting kedua setelah padi, baik sebagai sumber pangan maupun pakan. Meningkatnya laju pertumbuhan penduduk dan kebutuhan pangan, serta berkurangnya lahan pertanian akibat alih fungsi lahan untuk kepentingan non-pertanian, mendorong berbagai cara manipulasi tanaman dan lingkungan. Pola tanam tumpangsari merupakan salah satu solusi untuk peningkatan produktivitas. Ceunfin et al. (2017) menyatakan bahwa sistem tumpangsari lebih menguntungkan dibandingkan sistem monokultur karena produktivitas lahan menjadi tinggi, komoditas yang dihasilkan juga beragam, dan resiko kegagalan dapat diperkecil. Beberapa tanaman dapat ditumpangsarikan dengan jagung dan salah satunya adalah tanaman kedelai. Menurut Lihtourgidis et al. (2011), pola tanam tumpangsari dengan legume mampu memperbaiki tingkat kesuburan tanah melalui fiksasi nitrogen pada legume. Umumnya masyarakat melakukan pola tanam ganda dalam budidaya, padahal dengan melakukan beberapa macam pola tanam tumpangsari dapat menghasilkan produksi yang meningkat. Hasil penelitian Aminah et al. (2014) menunjukkan bahwa produksi jagung pipilan pada pola tanam 1:3 antara jagung dan kedelai adalah $3,512.8 \mathrm{~kg} \mathrm{ha}^{-1}$ dengan nilai NKL 1.59 .

Beberapa lahan dapat dijadikan alternatif untuk mengatasi kebutuhan pangan seperti lahan sawah yang dapat ditanam setelah penanaman padi, namun terdapat masalah yaitu kelebihan air sesaat. Menurut Ghulamahdi et al. (2006) keadaan ini umumnya terjadi pada pola penanaman dibeberapa daerah tropis dan sub-tropis, kelebihan air dapat terjadi karena periode yang panjang dari cuaca yang basah dan curah hujan yang tinggi setelah irigasi dan disebabkan karena adanya lapisan kedap air pada kedalaman 15-20 cm dibawah permukaan tanah. Permasalahan ini dapat diatasi dengan teknik budidaya jenuh air (BJA). Teknologi BJA dan tumpangsari akan menghasilkan iklim mikro yang berbeda dengan budidaya secara kering. Menurut Wentasari dan Sesanti (2016), pengaturan pola tanam pada tumpangsari bertujuan untuk menciptakan iklim mikro pada tanaman. Sistem tanam akan berpengaruh pada kerapatan populasi tanaman yang menyebabkan persaingan kebutuhan hidup antar individu, sehingga tercipta iklim yang khas pada satu populasi tanaman yang sering disebut iklim mikro.

Menurut Indrawan et al. (2017) tanaman merupakan sesuatu yang kompleks dan peka terhadap pengaruh iklim. Kondisi iklim akan mempengaruhi pertumbuhan dan produktivitas. Tanpa unsur iklim mikro, pertumbuhan tanaman akan tertahan meskipun beberapa tanaman dapat menyesuaikan diri untuk tetap hidup. Selain itu terdapat permasalahan lain dimana jagung merupakan tanaman untuk daerah kering dan sangat peka terhadap kondisi genangan. Namun pada kondisi tercekam jagung memberikan respon morfologi dan fisiologi terhadap adanya cekaman genangan (Utama dan Haryoko, 2019). Oleh karena itu, penggunaan beberapa varietas jagung ditujukan untuk mengetahui varietas yang adaptif pada sistem budidaya jenuh air. Penelitian ini bertujuan mempelajari pengaruh pola tanam tumpangsari beberapa varietas jagung dengan kedelai terhadap produktivitas kedua komoditi, serta hubungan antara iklim mikro (akibat pola tanam) dan produktivitas.

\section{BAHAN DAN METODE}

Penelitian dilaksanakan di Kebun Percobaan Sawah Baru IPB, Darmaga, Bogor pada bulan November 2018Februari 2019 dengan menggunakan rancangan petak terbagi (split-plot design). Petak utama yaitu pola tanam, terdiri atas monokultur, tumpangsari 1 baris jagung, tumpangsari 2 baris jagung, dan tumpangsari 3 baris jagung. Anak petak yaitu varietas, terdiri atas Sukmaraga (varietas komposit), Bima 19 (hibrida silang tiga jalur), dan BISI 2 (hibrida silang tunggal). Varietas kedelai Anjasmoro digunakan untuk perlakuan tumpangsari jagung-kedelai. Percobaan dilakukan dengan tiga ulangan.

Petak percobaan dibuat dengan ukuran $4 \mathrm{~m} \times 3 \mathrm{~m}$, dan dikelilingi oleh parit (dengan ukuran lebar $30 \mathrm{~cm}$ dan kedalaman $25 \mathrm{~cm}$ ). Air irigasi diberikan pada saat tanam dan berlanjut sampai tanaman dewasa. Jarak tanam jagung dibuat sesuai pola perlakuan, yaitu monokultur jagung dibuat dengan jarak $85 \mathrm{~cm} \times 25 \mathrm{~cm}$, tumpangsari 1 baris jagung dan kedelai dibuat jarak $240 \mathrm{~cm}$ x $25 \mathrm{~cm}$, tumpangsari 2 baris jagung dan kedelai dibuat jarak $240 \mathrm{~cm}$ x $40 \mathrm{~cm}$ x 25 $\mathrm{cm}$, tumpangsari 3 baris jagung dengan kedelai yaitu 240 $\mathrm{cm}$ x $30 \mathrm{~cm}$ x $25 \mathrm{~cm}$. Kedelai ditanam dengan jarak tanam $20 \mathrm{~cm}$ x $25 \mathrm{~cm}$ baik secara tumpangsari maupun monokultur dan ditanami 2 benih per lubang. Sebelum penanaman, benih kedelai diinokulasi dengan Rhizobium sp, dan pada saat penanaman benih jagung diberi Ridomil (mankozeb $64 \%$ dan mefenoksam 4\%). Pemberian pupuk pada tanaman jagung diberikan dengan dosis $300 \mathrm{~kg}$ SP-36 ha-1, $150 \mathrm{~kg}$ $\mathrm{KCl} \mathrm{ha}{ }^{-1}, 150 \mathrm{~kg}$ Urea ha ${ }^{-1}$ pada saat tanam, dan $150 \mathrm{~kg} \mathrm{ha}^{-1}$ setelah 30 hari tanam. Pemberian pupuk urea pada jagung dan kedelai juga dilakukan ketika umur tanaman 2, 3, 4, 5 MST dengan konsentrasi urea $15 \mathrm{~g} \mathrm{~L}^{-1}$ air, dengan cara disemprotkan ke daun menggunakan knapsack sprayer dengan volume semprot air $400 \mathrm{~L} \mathrm{ha}^{-1}$.

Pemanenan jagung dilakukan setelah masak fisiologi atau telah mulai membentuk lapisan hitam/ black layer minimal 50\% dan pemanenan kedelai dilakukan saat $90 \%$ populasi tanaman telah luruh daunnya serta polong berwarna kuning kecoklatan. Produktivitas dihitung dari sistem ubinan berukuran $4 \mathrm{~m} \times 2 \mathrm{~m}$.

Peubah yang diamati dalam penelitian ini meliputi iklim mikro yang diamati menggunakan Benetch data logger pengukur suhu dan kelembaban, setiap minggu pengamatan pada pukul 06:00, 12:00, dan 17:00 WIB. Pengamatan dilakukan 3 waktu kemudian dirata-rata. Pengamatan produktivitas tanaman jagung maupun kedelai terdiri atas, bobot biji per ubinan, produktivitas, dan nisbah kesetaraan lahan (NKL). Perhitungan NKL mengikuti Beets (1982) untuk mengetahui efesiensi penggunaan lahan. Analisis data dilakukan dengan analisis ragam. Apabila suatu faktor berpengaruh nyata terhadap karakter yang diamati, maka dilakukan uji perbedaan nilai tengah dengan metode Duncan multiple range test (DMRT) pada taraf 5\%. Analisis korelasi dan regresi dilakukan untuk mempelajari hubungan antara iklim mikro dan produktivitas. 


\section{HASIL DAN PEMBAHASAN}

\section{Suhu dan Kelembaban Relatif Pertanaman Jagung}

Interaksi antara pola tanam dan varietas jagung berpengaruh nyata terhadap suhu pertanaman jagung (Tabel 1). Pola tanam monokultur menyebabkan suhu di sekitar tanaman jagung lebih tinggi dibandingkan dengan tumpangsari. Ketika memasuki umur 6 MST dan 8 MST, tanaman dengan pola tumpangsari saling menaungi sehingga suhu pertanaman pada pola tumpangsari dapat lebih rendah. Hal ini sejalan dengan pendapat Indrawan et al. (2017) bahwa perlakuan berbagai pola tanam dan populasi berpengaruh nyata pada suhu karena perubahan suhu udara di sekitar tanaman disebabkan oleh pola tanam dan populasi kerapatan tanaman. Tabel 1 menunjukkan bahwa perbedaan varietas yang digunakan berpengaruh terhadap suhu di sekitar tanaman.

Tabel 1 juga menunjukkan pengaruh interaksi antara pola tanam dengan berbagai varietas jagung terhadap kelembaban relatif udara. Kurangnya sinar matahari yang diterima akibat terhalang oleh daun menyebabkan kelembaban pada umur 4 MST dan 8 MST menjadi lebih tinggi dan menurunkan suhu udara di sekitar tanaman. Ketika umur 6 MST semua perlakuan tidak memberikan respon nyata pada kelembaban relatif. Hal ini diduga bahwa perbedaan suhu yang diakibatkan oleh perlakuan tidak menyebabkan perbedaan kemampuan mengandung uap air di udara sehingga kelembaban relatif semua perlakuan sama. Jumlah uap air yang dapat dikandung udara ditentukan oleh suhu udara. Wentasari dan Gusta (2018) menyatakan bahwa perubahan suhu adalah faktor yang mengatur perubahan kelembaban relatif udara harian.

\section{Suhu dan Kelembaban Relatif Pertanaman Kedelai}

Tabel 2 menunjukkan bahwa terdapat interaksi antara berbagai pola tanam dan varietas jagung yang digunakan. Suhu sekitar tanaman kedelai bervariasi hal ini disebabkan karena pada setiap pertumbuhan dan pola tanaman jagung yang digunakan mempengaruhi suhu, dimana semakin rapat tanaman jagung membuat suhu sekitar tanaman kedelai semakin rendah. Hal ini terlihat pada percobaan disetiap pola tanam yang digunakan. Ketika umur 4, 6, 8 MST, suhu tanaman kedelai pada pola tanam tumpangsari 1 baris jagung lebih tinggi, namun pada pola tanam tumpangsari 2 baris jagung suhu sekitar tanaman kedelai menurun dan semakin menurun pada pola tanaman 3 baris jagung.

Kelembaban di sekitar tanaman kedelai dipengaruhi oleh perbedaan varietas tanaman jagung dan pola tanam yang digunakan. Semakin bertambahnya tinggi tanaman jagung membuat semakin tinggi kelembaban di sekitar tanaman kedelai. Hal ini dikarenakan tanaman jagung menaungi tanaman kedelai sehingga suhu di sekitar tanaman menurun dan kelembaban tinggi (Tabel 2). Hal ini pun sesuai dengan pendapat Arta et al. (2019) bahwa semakin rendahnya suhu maka semakin tinggi kelembaban. Pada tanaman kedelaipun ketika umur 6 MST semua perlakuan tidak memberikan respon nyata pada kelembaban relatif. Hal ini sama seperti kelembaban pada tanaman jagung; diduga bahwa perbedaan

Tabel 1. Suhu dan kelembaban di sekitar tanaman jagung pada berbagai perlakuan pola tanam tumpangsari jagung dengan kedelai

\begin{tabular}{|c|c|c|c|c|c|c|}
\hline \multirow{2}{*}{ Pola tanam } & \multicolumn{3}{|c|}{ Suhu $\left({ }^{\circ} \mathrm{C}\right)$} & \multicolumn{3}{|c|}{ Kelembaban (\%) } \\
\hline & Sukmaraga & Bima 19 & BISI 2 & Sukmaraga & Bima 19 & BISI 2 \\
\hline & \multicolumn{6}{|c|}{$4 \mathrm{MST}$} \\
\hline Tumpangsari 1 baris jagung & $27.47 \mathrm{abc}$ & $27.47 \mathrm{abc}$ & $27.51 \mathrm{a}$ & $79.09 b c$ & $79.06 \mathrm{c}$ & $79.10 \mathrm{bc}$ \\
\hline Tumpangsari 2 baris jagung & $27.43 \mathrm{~cd}$ & $27.46 \mathrm{abcd}$ & $27.42 \mathrm{~d}$ & $79.11 b c$ & $79.15 \mathrm{ab}$ & $79.20 \mathrm{a}$ \\
\hline Tumpangsari 3 baris jagung & $27.46 \mathrm{bcd}$ & $27.45 \mathrm{bcd}$ & $27.43 \mathrm{~cd}$ & $79.20 \mathrm{a}$ & $79.12 b c$ & $79.15 \mathrm{ab}$ \\
\hline \multirow[t]{2}{*}{ Monokultur jagung } & $27.48 \mathrm{ab}$ & $27.49 \mathrm{ab}$ & $27.48 \mathrm{ab}$ & $79.16 \mathrm{ab}$ & $79.16 \mathrm{ab}$ & $79.16 \mathrm{ab}$ \\
\hline & \multicolumn{6}{|c|}{$6 \mathrm{MST}$} \\
\hline Tumpangsari 1 baris jagung & $27.44 \mathrm{bc}$ & $27.42 \mathrm{bc}$ & $27.47 \mathrm{~b}$ & 84.12 & 84.19 & 84.23 \\
\hline Tumpangsari 2 baris jagung & $27.43 \mathrm{bc}$ & $27.43 b c$ & $27.43 \mathrm{bc}$ & 84.21 & 84.14 & 84.12 \\
\hline Tumpangsari 3 baris jagung & $27.37 \mathrm{c}$ & $27.39 b c$ & $27.41 b c$ & 84.17 & 84.23 & 84.13 \\
\hline \multirow[t]{2}{*}{ Monokultur jagung } & $27.58 \mathrm{a}$ & $27.59 \mathrm{a}$ & $27.58 \mathrm{a}$ & 84.15 & 84.12 & 84.10 \\
\hline & \multicolumn{6}{|c|}{$8 \mathrm{MST}$} \\
\hline Tumpangsari 1 baris jagung & $27.40 \mathrm{bc}$ & $27.42 b c$ & $27.47 \mathrm{~b}$ & $84.39 \mathrm{bcd}$ & $84.37 \mathrm{~d}$ & $84.38 \mathrm{~cd}$ \\
\hline Tumpangsari 2 baris jagung & $27.44 b c$ & $27.44 \mathrm{bc}$ & $27.45 b c$ & $84.38 \mathrm{~cd}$ & $84.40 \mathrm{bcd}$ & $84.40 \mathrm{bcd}$ \\
\hline Tumpangsari 3 baris jagung & $27.37 \mathrm{c}$ & $27.38 b c$ & $27.40 \mathrm{bc}$ & $84.50 \mathrm{abc}$ & $84.41 \mathrm{bcd}$ & $84.51 \mathrm{ab}$ \\
\hline Monokultur jagung & $27.58 \mathrm{a}$ & $27.59 \mathrm{a}$ & $27.57 \mathrm{a}$ & 84.45abcd & $84.38 \mathrm{~cd}$ & $84.56 \mathrm{a}$ \\
\hline
\end{tabular}

Keterangan: Angka yang diikuti oleh huruf yang sama pada masing-masing peubah tidak berbeda nyata berdasarkan uji DMRT pada $\alpha=$ $5 \%$. Suhu dan kelembaban diukur pada bagian tengah tajuk tanaman. 
Tabel 2. Suhu dan kelembaban di sekitar tanaman kedelai pada berbagai perlakuan pola tanam tumpangsari jagung dengan kedelai

\begin{tabular}{|c|c|c|c|c|c|c|}
\hline \multirow{2}{*}{ Pola tanam } & \multicolumn{3}{|c|}{ Suhu $\left({ }^{\circ} \mathrm{C}\right)$} & \multicolumn{3}{|c|}{ Kelembaban (\%) } \\
\hline & Sukmaraga & Bima 19 & BISI 2 & Sukmaraga & Bima 19 & BISI 2 \\
\hline & \multicolumn{6}{|c|}{$4 \mathrm{MST}$} \\
\hline Tumpangsari 1 baris jagung & $24.92 \mathrm{ab}$ & $24.93 \mathrm{ab}$ & $24.96 \mathrm{a}$ & $76.84 \mathrm{bc}$ & $76.81 \mathrm{c}$ & $76.85 \mathrm{bc}$ \\
\hline Tumpangsari 2 baris jagung & $24.86 \mathrm{ab}$ & $24.92 \mathrm{ab}$ & $24.88 \mathrm{ab}$ & $76.86 \mathrm{bc}$ & 76.90ab & $76.95 \mathrm{a}$ \\
\hline \multirow[t]{2}{*}{ Tumpangsari 3 baris jagung } & $24.85 b$ & $24.87 \mathrm{ab}$ & $24.86 \mathrm{ab}$ & $76.95 \mathrm{a}$ & $76.87 \mathrm{bc}$ & $76.90 \mathrm{ab}$ \\
\hline & \multicolumn{6}{|c|}{$6 \mathrm{MST}$} \\
\hline Tumpangsari 1 baris jagung & $25.94 \mathrm{ab}$ & $25.92 \mathrm{ab}$ & $25.97 \mathrm{a}$ & 82.18 & 82.19 & 82.23 \\
\hline Tumpangsari 2 baris jagung & $25.94 \mathrm{ab}$ & $25.93 \mathrm{ab}$ & $25.93 \mathrm{ab}$ & 82.21 & 82.15 & 82.13 \\
\hline \multirow[t]{2}{*}{ Tumpangsari 3 baris jagung } & $25.87 b$ & $25.89 \mathrm{ab}$ & $25.90 \mathrm{ab}$ & 82.18 & 82.18 & 82.14 \\
\hline & \multicolumn{6}{|c|}{$8 \mathrm{MST}$} \\
\hline Tumpangsari 1 baris jagung & 26.44 & 26.42 & 26.47 & $83.39 \mathrm{ab}$ & $83.37 b$ & $83.38 \mathrm{ab}$ \\
\hline Tumpangsari 2 baris jagung & 26.44 & 26.44 & 26.45 & $83.38 \mathrm{ab}$ & $83.40 \mathrm{ab}$ & $83.40 \mathrm{ab}$ \\
\hline Tumpangsari 3 baris jagung & 26.37 & 26.38 & 26.40 & $83.50 \mathrm{a}$ & $83.41 \mathrm{ab}$ & $83.50 \mathrm{a}$ \\
\hline
\end{tabular}

Keterangan: Angka yang diikuti oleh huruf yang sama pada masing-masing peubah tidak berbeda nyata berdasarkan uji DMRT pada $\alpha=$ $5 \%$. Suhu dan kelembaban diukur pada bagian tengah tajuk tanaman.

suhu yang diakibatkan oleh perlakuan tidak menyebabkan perbedaan kemampuan mengandung uap air di udara sehingga kelembaban relatif semua perlakuan sama.

\section{Komponen Produktivitas Tanaman Jagung}

Pola tanam tumpangsari berpengaruh nyata pada bobot kering biji jagung per ubinan dan produktivitas (Tabel 3). Pola tanam tumpangsari 3 baris jagung menyebabkan bobot biji per ubinan lebih besar dibandingkan dengan yang lain.
Pada produktivitas pola tanam 2 baris jagung lebih besar dibandingkan yang lain. Hal ini berkaitan dengan jarak tanam yang digunakan pada tiap perlakuan pola tanam tumpangsari yaitu jarak tanam yang sempit akan meningkatkan produksi seperti yang dinyatakan oleh Wahyudin et al. (2017), dengan syarat faktor pembatas dapat dihindari agar tidak terjadi persaingan. Menurut Atmaja (2017) hara tanaman sering menjadi faktor pembatas bagi pertumbuhan dan hasil tanaman. Vera et al. (2020) jarak tanam yang rapat mengakibatkan proses penyerapan unsur hara menjadi

Tabel 3. Produksi tanaman jagung pada berbagai pola tanam tumpangsari jagung dan kedelai dengan tiga varietas jagung

\begin{tabular}{|c|c|c|c|c|}
\hline \multirow{2}{*}{ Pola tanam } & \multicolumn{3}{|c|}{ Varietas jagung } & \multirow{2}{*}{ Rataan } \\
\hline & Sukmaraga & Bima 19 & BISI 2 & \\
\hline & \multicolumn{4}{|c|}{ Bobot biji per ubinan $\left(\mathrm{g} 8 \mathrm{~m}^{-2}\right)$} \\
\hline Tumpangsari 1 baris jagung & $2,784.60 \mathrm{~d}$ & $2,327.10 \mathrm{~d}$ & $2,889.20 \mathrm{~d}$ & $2,667.00 \mathrm{c}$ \\
\hline Tumpangsari 2 baris jagung & $5,187.40 \mathrm{c}$ & $5,275.90 \mathrm{bc}$ & $5,879.10 \mathrm{ab}$ & $5,447.50 \mathrm{~b}$ \\
\hline Tumpangsari 3 baris jagung & $5,482.20 \mathrm{abc}$ & $5,600.30 \mathrm{abc}$ & $5,787.20 \mathrm{abc}$ & $5,623.20 \mathrm{~b}$ \\
\hline Monokultur jagung & $5,964.00 \mathrm{a}$ & $6,051.50 \mathrm{a}$ & $5,982.20 \mathrm{a}$ & $5,999.20 \mathrm{a}$ \\
\hline \multirow[t]{2}{*}{ Rataan } & $4,854.60 \mathrm{~b}$ & $4,813.70 \mathrm{~b}$ & $5,134.43 a$ & \\
\hline & \multicolumn{4}{|c|}{ Produktivitas $\left(\right.$ ton $\left.\mathrm{ha}^{-1}\right)$} \\
\hline Tumpangsari 1 baris jagung & $3.46 \mathrm{c}$ & $2.93 \mathrm{c}$ & $3.60 \mathrm{c}$ & $3.33 \mathrm{c}$ \\
\hline Tumpangsari 2 baris jagung & $6.50 \mathrm{~b}$ & $6.56 \mathrm{~b}$ & $7.33 \mathrm{a}$ & $6.80 \mathrm{~b}$ \\
\hline Tumpangsari 3 baris jagung & $6.86 \mathrm{ab}$ & $7.00 \mathrm{ab}$ & $7.23 \mathrm{ab}$ & $7.03 b$ \\
\hline Monokultur jagung & $7.43 \mathrm{a}$ & $7.56 \mathrm{a}$ & $7.46 \mathrm{a}$ & $7.48 \mathrm{a}$ \\
\hline Rataan & $6.06 \mathrm{ab}$ & $6.01 \mathrm{~b}$ & $6.40 \mathrm{a}$ & \\
\hline
\end{tabular}

Keterangan: Angka yang diikuti oleh huruf yang sama antar kombinasi perlakuan dan antar rataan perlakuan tidak berbeda nyata berdasarkan uji DMRT pada $\alpha=5 \%$ 
kurang efesien, karena kondisi perakaran di dalam tanah yang saling bertaut sehingga kompetisi antar tanaman dalam mendapatkan unsur hara menjadi lebih besar. Harjadi (2002) menambahkan bahwa jarak tanam mempengaruhi persaingan antar tanaman dalam mendapatkan air dan unsur hara, sehingga akan mempengaruhi hasil.

Urutan produktivitas jagung dari yang tertinggi pada berbagai pola tanam tumpangsari rata-rata yaitu varietas BISI 2, Bima 19 dan terakhir Sukmaraga. Varietas BISI 2 dan Bima 19 hampir memiliki nilai produksi yang berdekatan baik secara tumpangsari maupun monokultur, hal ini diduga karena varietas BISI 2 dan Bima 19 merupakan varietas hibrida. Sari et al. (2018) menyatakan bahwa varietas hibrida merupakan varietas unggul hasil pemuliaan tanaman yang mampu berproduksi 15\% lebih baik dibandingkan varietas bersari bebas. Roupahim et al. (2016) menyatakan bahwa varietas hibrida mempunyai adaptasi terhadap jenis tanah dan iklim, termasuk iklim mikro. Pada penelitian ini, rata-rata hasil varietas BISI 2 (6.40 ton ha $\left.{ }^{-1}\right)$ tidak berbeda nyata dengan Sukmaraga (6.06 ton $\mathrm{ha}^{-1}$ ) dan lebih tinggi dari Bima 19 (6.01 ton $\mathrm{ha}^{-1}$ ) (Tabel 3). Menurut Syuryawati dan Faesal (2016) hasil yang tinggi berpengaruh terhadap biaya pengolahan hasil; besarnya penerimaan dan keuntungan akan menentukan efisiensi ekonomi usaha atau kelayakan teknologi. Rachman dan Saryoko (2008) menjelaskan keuntungan usahatani jagung dipengaruhi oleh teknik budidaya yang diterapkan, harga yang berlaku, dan hasil yang dicapai.

\section{Komponen Produktivitas Tanaman Kedelai}

Interaksi antara pola tanam dan varietas jagung berpengaruh nyata terhadap bobot biji per ubinan dan produktivitas kedelai (Tabel 4). Bobot biji kedelai per ubinan tertinggi ditujukan pada sistem pola tanam 1 baris jagung dengan varietas jagung BISI 2 (1,743.30 g), dengan produktivitas sebesar 2.16 ton ha $^{-1}$. Sebaliknya, bobot biji kedelai per ubinan dan produktivitas terendah terdapat pada sistem pola tanam tumpangsari 2 baris jagung dengan varietas BISI 2.

Penurunan hasil tanaman kedelai pada pola tumpangsari terhadap produksi total dimungkinkan oleh pengaruh naungan dari tanaman jagung terhadap kedelai dan kepadatan populasi tanaman kedelai, sehingga cahaya yang diterima oleh kedelai berkurang dan mempengaruhi fase generatif. Hal ini sesuai dengan pendapat Sari (2019) bahwa akumulasi fotosintat dari polong ke biji dipengaruhi oleh intensitas cahaya, sehingga pengisian polong dan biji akan terganggu jika terjadi naungan.

\section{Hubungan Iklim Mikro dengan Produktivitas Jagung}

Iklim mikro, diantaranya yaitu suhu dan kelembaban, dapat mempengaruhi pertumbuhan dan produksi tanaman. Menurut Herlina dan Prasetyorini (2020), suhu tinggi dapat mengakibatkan penurunan ketersediaan air pada tanaman dan berpengaruh pada proses pertumbuhan jagung serta produksi tanaman, akan tetapi jika ketersediaan air cukup, maka peningkatan suhu dapat meningkatkan produktivitas jagung.

Berdasarkan Gambar 1 dapat diketahui bahwa $\mathrm{y}=$ 2.1818x-48.892, dengan nilai $\mathrm{R}^{2}$ pada persamaan adalah 0.021. Nilai tersebut menunjukkan bahwa hanya $2.1 \%$ keragaman produktivitas yang dapat dijelaskan oleh suhu tanaman. Sementara itu pada Gambar 2, untuk kelembaban terlihat bahwa $\mathrm{y}=-4.5555 \mathrm{x}+391$ dengan nilai $\mathrm{R}^{2}$ sebesar 0.045 yang menunjukkan bahwa keragaman produktivitas yang dapat dijelaskan oleh kelembaban hanya sebesar $4.5 \%$. Pada Gambar 2 terlihat tren negatif yang menandakan bahwa semakin tinggi kelembaban sekitar tanaman maka semakin rendah produktivitasnya.

Nilai $\mathrm{R}^{2}$ pada suhu dan kelembaban menunjukan nilai kecil diduga karena variasi suhu tanaman $\left(25.1-25.5{ }^{\circ} \mathrm{C}\right)$ antar perlakuan sempit, demikian juga dengan kelembaban

Tabel 4. Produksi tanaman kedelai pada berbagai pola tanam tumpangsari jagung dan kedelai dengan tiga varietas jagung

\begin{tabular}{|c|c|c|c|c|}
\hline \multirow{2}{*}{ Pola tanam } & \multicolumn{3}{|c|}{ Varietas } & \multirow{2}{*}{ Rataan } \\
\hline & Sukmaraga & Bima 19 & BISI 2 & \\
\hline & \multicolumn{4}{|c|}{ Bobot biji per ubinan (g per $8 \mathrm{~m}^{2}$ ) } \\
\hline Tumpangsari 1 baris jagung & $1,447.30 \mathrm{a}$ & $1,446.30 \mathrm{ab}$ & $1,743.30 \mathrm{ab}$ & $1,545.63 \mathrm{a}$ \\
\hline Tumpangsari 2 baris jagung & $1,061.70 \mathrm{ab}$ & $1,196.30 \mathrm{ab}$ & $844.00 b$ & $1,034.00 \mathrm{~b}$ \\
\hline Tumpangsari 3 baris jagung & $964.70 \mathrm{ab}$ & $1,022.00 \mathrm{ab}$ & $1,174.70 \mathrm{ab}$ & $1,053.80 \mathrm{~b}$ \\
\hline \multirow[t]{2}{*}{ Rataan } & $1,157.90$ & $1,221.56$ & $1,254.00$ & \\
\hline & \multicolumn{4}{|c|}{ Produktivitas (ton ha ${ }^{-1}$ ) } \\
\hline Tumpangsari 1 baris jagung & $1.83 \mathrm{ab}$ & $1.80 \mathrm{ab}$ & $2.16 \mathrm{a}$ & $1.93 \mathrm{a}$ \\
\hline Tumpangsari 2 baris jagung & $1.33 \mathrm{ab}$ & $1.50 \mathrm{ab}$ & $1.43 b$ & $1.42 b$ \\
\hline Tumpangsari 3 baris jagung & $1.20 \mathrm{ab}$ & $0.90 \mathrm{ab}$ & $1.46 \mathrm{ab}$ & $1.18 \mathrm{~b}$ \\
\hline Rataan & 1.45 & 1.40 & 1.68 & \\
\hline
\end{tabular}

Keterangan: Angka yang diikuti oleh huruf yang sama antar kombinasi perlakuan dan antar rataan perlakuan tidak berbeda nyata berdasarkan uji DMRT pada $\alpha=5 \%$ 


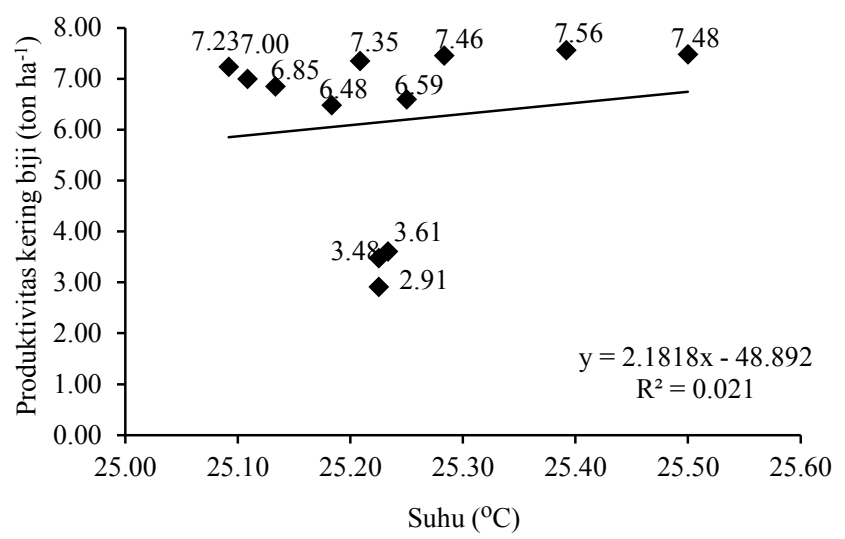

Gambar 1. Hubungan suhu dengan produktivitas jagung pipilan kering

(83.4-83.6\%), sehingga pola hubungan yang sebenarnya belum dapat dipelajari. Menurut Rudianto et al. (2017), jagung membutuhkan kelembaban udara sedang sampai tinggi (50-80\%) agar keseimbangan metabolisme tanaman dapat berlangsung dengan optimal.

\section{Hubungan Iklim Mikro dengan Produktivitas Kedelai}

Gambar 3 memperlihatkan regresi antara produktivitas tanaman kedelai terhadap suhu tanaman kedelai, dengan persamaan $\mathrm{y}=4.35 \mathrm{x}-105.78\left(\mathrm{R}^{2}=0.46\right)$. Hal ini menunjukan bahwa suhu tanaman kedelai pada beberapa pola tanam yang digunakan mampu menjelaskan keragaman produktivitas tanaman kedelai sebesar 46\%. Pada penelitian ini diketahui juga bahwa pengaruh suhu tanaman kedelai terhadap produktivitas kedelai lebih besar daripada pengaruh suhu tanaman jagung terhadap produktivitas jagung.

Regresi antara produktivitas kedelai terhadap kelembaban tanaman kedelai (Gambar 4) menghasilkan persamaan $\mathrm{y}=-0.09 \mathrm{x}+9.31$ dengan nilai $\mathrm{R}^{2}$ sebesar 0.0003. Nilai $R^{2}$ tersebut menunjukkan bahwa kelembaban tanaman hanya dapat menjelaskan $0.03 \%$ dari keragaman produktivitas kedelai. Pengaruh yang kecil dari kelembaban tanaman terhadap produktivitas kedelai terlihat dari pola garis regresi yang mendatar. Perubahan kelembaban yang

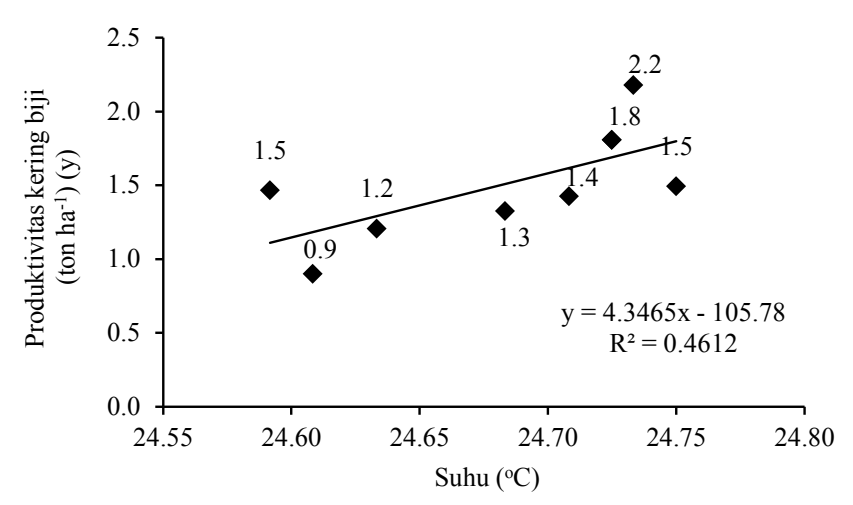

Gambar 3. Hubungan suhu dengan produktivitas kedelai

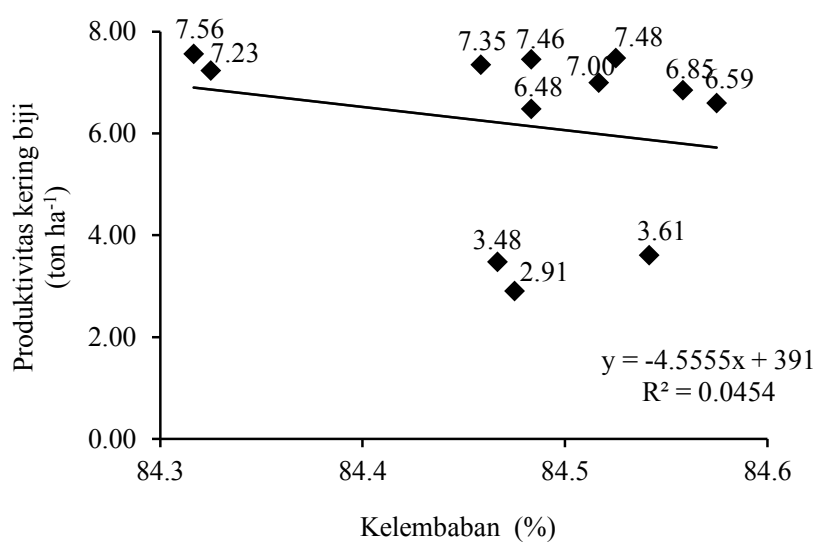

Gambar 2. Hubungan kelembaban dengan produktivitas jagung pipilan kering

ada pada tiap-tiap pola tanam bisa berdampak meningkatkan atau dapat menurunkan produktivitas tergantung pada faktor pembatas lainnya dapat diatasi atau tidak.

\section{Evaluasi Lahan}

Evaluasi terhadap peningkatan atau penurunan hasil pada pola tanam tumpangsari terdapat tiga kemungkinan, hasil tumpangsari lebih menguntungkan daripada monokultur (NKL $>1$ ), hasil tumpangsari tidak menguntungkan $(\mathrm{NKL}<1)$ dan hasil tumpangsari sama dengan monokultur (NKL=1) (Iyoyah et al., 2013; Arifin et al., 2014). Hasil penelitian Sundari dan Mutmaidah (2018) NKL kisaran 1.1-1.9 produktivitas lahan tumpangsari lebih efisien $50 \%$ dan dapat meningkatkan hasil dibandingkan dengan produktivitas lahan monokultur.

Hasil percobaan menunjukkan bahwa pola tanam tumpangsari dengan 2 baris jagung (rataan NKL $=1.35$ ) ataupun 3 baris jagung (rataan NKL $=1.31$ ) dapat lebih meningkatkan produktivitas lahan dibandingkan dengan sistem pola tanam 1 baris jagung (rataan NKL $=1.05$ ) (Tabel 5). Hal ini mengindikasikan bahwa pola tanam tumpangsari 2-3 baris jagung dengan kedelai potensial untuk dikembangkan. Menurut Ceunfin et al. (2017) peningkatan produktivitas pada lahan tumpangsari disebabkan karena

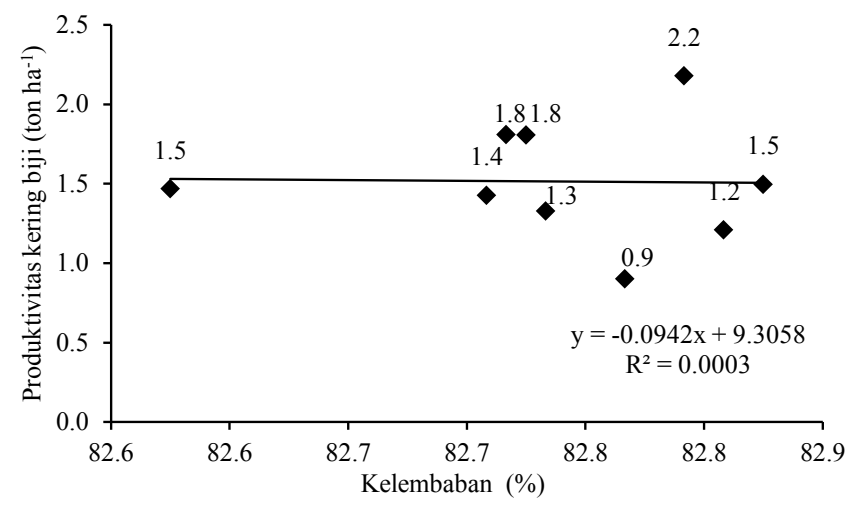

Gambar 4. Hubungan kelembaban dengan produktivitas kedelai 
Tabel 5. Nisbah keseteraan lahan (NKL) pada berbagai pola tanam tumpangsari jagung dan kedelai dengan tiga varietas jagung

\begin{tabular}{|c|c|c|c|c|c|c|c|c|c|c|c|}
\hline \multirow{2}{*}{$\begin{array}{l}\text { Varietas } \\
\text { jagung }\end{array}$} & \multicolumn{3}{|c|}{$\begin{array}{l}\text { Hasil jagung tumpangsari } \\
\left.\text { (ton } \mathrm{ha}^{-1}\right)\end{array}$} & \multirow{2}{*}{$\begin{array}{c}\text { Hasil } \\
\text { jagung } \\
\text { monokultur } \\
\left(\text { ton } \text { ha }^{-1}\right)\end{array}$} & \multicolumn{3}{|c|}{$\begin{array}{c}\text { Hasil kedelai } \\
\left.\text { tumpangsari (ton } \mathrm{ha}^{-1}\right)\end{array}$} & \multirow{2}{*}{$\begin{array}{c}\text { Hasil } \\
\text { kedelai } \\
\text { monokultur } \\
\left(\text { ton } \text { ha }^{-1}\right)\end{array}$} & \multicolumn{3}{|c|}{ NKL } \\
\hline & $\begin{array}{l}1 \text { baris } \\
\text { jagung }\end{array}$ & $\begin{array}{l}2 \text { baris } \\
\text { jagung }\end{array}$ & $\begin{array}{l}3 \text { baris } \\
\text { jagung }\end{array}$ & & $\begin{array}{l}1 \text { baris } \\
\text { jagung }\end{array}$ & $\begin{array}{l}2 \text { baris } \\
\text { jagung }\end{array}$ & $\begin{array}{l}3 \text { baris } \\
\text { jagung }\end{array}$ & & $\begin{array}{l}1 \text { baris } \\
\text { jagung }\end{array}$ & $\begin{array}{l}2 \text { baris } \\
\text { jagung }\end{array}$ & $\begin{array}{l}3 \text { baris } \\
\text { jagung }\end{array}$ \\
\hline Sukmaraga & 3.48 & 6.48 & 6.85 & 7.46 & 1.81 & 1.33 & 1.21 & 3.2 & 1.03 & 1.28 & 1.30 \\
\hline Bima 19 & 2.91 & 6.59 & 7.00 & 7.56 & 1.81 & 1.50 & 0.90 & 3.2 & 0.95 & 1.34 & 1.21 \\
\hline BISI 2 & 3.61 & 7.35 & 7.23 & 7.48 & 2.18 & 1.43 & 1.47 & 3.2 & 1.16 & 1.43 & 1.43 \\
\hline Rataan & 3.33 & 6.81 & 7.03 & 7.50 & 1.93 & 1.42 & 1.19 & 3.2 & 1.05 & 1.35 & 1.31 \\
\hline
\end{tabular}

pemilihan kombinasi tanaman dan sistem pertanaman yang tepat serta adanya hubungan simbiosis mutualisme antar tanaman yang ditanam secara tumpangsari. Simbiosis ini berhubungan dengan kebutuhan nitrogen pada tanaman utama yang dipenuhi dari tanaman sisipan melalui kemampuannya dalam memfikasasi nitrogen. Rochmah et al. (2020) menambahkan kombinasi serealia dengan tanaman legume adalah yang terbaik dalam hal memperoleh sinar matahari dan unsur hara.

\section{KESIMPULAN}

Produktivitas yang dihasilkan pada pola tanam tumpangsari 2 baris jagung rata-rata 6.40 ton $\mathrm{ha}^{-1}$ dengan nilai NKL 1.43 dan produktivitas pada pola tanam 3 baris jagung rata-rata 6.01 ton $\mathrm{ha}^{-1}$ dengan nilai NKL 1.43. Setiap pola tanam dan varietas yang digunakan menghasilkan iklim mikro yang berbeda. Suhu pertanaman dan kelembaban relatif tanaman jagung bervariasi akibat perbedaan pola tanam dan kerapatan populasi. Pada tanaman kedelai suhu pertanaman dan kelembaban relatif berbeda akibat pertumbuhan dan pola tanaman jagung menaungi tanaman kedelai. Sebesar 2.1\% suhu dan 4.5\% kelembaban mempengaruhi produktivitas tanaman jagung, sementara itu $46 \%$ suhu dan $0.03 \%$ kelembaban mempengaruhi produktivitas tanaman kedelai. Pengaruh suhu tanaman kedelai terhadap produktivitas kedelai lebih besar daripada pengaruh suhu tanaman jagung hal ini terjadi akibat tanaman kedelai ternaungi oleh tanaman jagung.

\section{DAFTAR PUSTAKA}

Arifin, Z., Suwono, D.M. Arsyad. 2014. Pengaruh sistem tanam dan pemangkasan tanaman terhadap pertumbuhan serta hasil jagung dan kedelai. J. Pengkajian Pengemb. Tek. Pert. 1:15-26.

Aminah, I.S., Rosmiah, M.H. Yahya. 2014. Efisiensi pemanfaatan lahan pada tumpangsari jagung (Zea mays L.) dan kedelai (Glycine max L.) di lahan pasang surut. J. Lahan Suboptimal 3:62-70.
Arta, I.M.W.G., Sumiyati, I.A.B. Madrini. 2019.Analisis profil iklim mikro pada budidaya cabai rawit (Capsicum frutescens L.) menggunakan bahan sungkup plastik, paranet, dan kombinasi. J. Beta. $1: 144-152$.

Beets, W.C. 1982. Multiple Cropping and Tropical Farming System. Gower Publ. Co. Chicago, USA.

Ceunfin, S., D. Prajitno, P. Suryanto, E.T.S. Putra. 2017. Penilaian kompetisi dan keuntungan hasil tumpangsari jagung kedelai di bawah tegakan kayu putih. J. Pertanian Konservasi Lahan Kering 2:1-3.

Ghulamahdi, M., S.A. Aziz, M. Melati, N. Dewi, S.A. Rais. 2006. Aktivitas nitrogenase, serapan hara dan pertumbuhan dua varietas kedelai pada kondisi jenuh air dan kering. Bul. Agron. 34:32-38.

Herlina, N., A. Prasetyorini. 2020. Pengaruh perubahan iklim pada musim tanam dan produktivitas jagung (Zea mays L.) di Kabupaten Malang. J. Ilmu Pertanian Indonesia 25:118-128.

Indrawan, R.R., A. Suryanto, R. Soelistyono. 2017. Kajian iklim mikro terhadap berbagai sistem tanam dan populasi tanaman jagung manis. J. Prod. Tan. 5:9299.

Iyoyah, M.O., A.O. Ogas, G.O.S. Ojo. 2013. Soybean maize intercropping on yield and system productivity in Makurdi Central Nigeria. Sci. J. Crop Sci. 4:49-55.

Lihtourgidis, A.S., C.A. Dorgas, C.A. Damalas, D.N. Vlachostergios. 2011. Annual intercrops: an alternative pathway for sustainable agriculture. Aus. J. Crop Sci. 5:396-410.

Rachman, B., A. Saryoko. 2008. Analisis titik impas dan laba usahatani melalui pendekatan dan pengelolaan padi terpadu di Kabupaten Lebak, Banten. J. Pengkajian Pengemb. Tek. Pert. 11:54-60. 
Rochmah, H.F., Suwarto, A.A. Muliasari. 2020. Optimasi lahan replanting kelapa sawit dengan sistem tumpangsari jagung (Zea mays L.) dan kacang tanah (Arachis hypogaea L.). J. Simetrik 1:256-262.

Roupahim, I.S. Aminah, Gusmiatun. 2016. Pengaruh pemberian jenis pupuk hayati terhadap pertumbuhan dan produksi beberapa verietas jagung hibrida (Zea mays L.). J. Klorofil 9:26-31.

Rudianto, G., D. Indradewa, S.N.H. Utami. 2017. Pengaruh ketebalan abu volkan di atas permukaan tanah yang jatuh pada berbagai fase tumbuh terhadap pertumbuhan dan hasil jagung (Zea mays L.). J. Vegetalika 6:1-11.

Sari, L.A. 2019. Pertumbuhan hasil jagung dan kacang tunggak dalam sistem tumpangsari. J. Pertanian 2:93-116.

Sari, P.M., M. Surahman, C. Budiman. 2018. Peningkatan produksi dan mutu benih jagung hibrida melalui aplikasi pupuk N, P, K, dan bakteri probiotik. Bul. Agrohorti 6: 412-421.

Sundari, T., S. Mutmaidah. 2018. Identifikasi kesesuaian genotipe kedelai untuk tumpangsari dengan ubi kayu. J. Ilmu Pertanian Indonesia 1:29-37.
Syuryawati, Faesal. 2016 Kelayakan finansial penerapan teknologi budi daya jagung pada lahan sawah tadah hujan. J. Penelitian Pertanian Tanaman Pangan. 35:71-80.

Utama, M.J.H., W. Haryoko. 2019. Mekanisme adaptasi jagung terhadap cekaman $\mathrm{NaCl}$ : pola serapan anion dan kation. J. Agron. Indonesia 47:255-261.

Vera, D.Y.S., E. Turmudi, E. Suprijono. 2020. Pengaruh jarak tanam dan frekuensi penyiangan terhadap pertumbuhan, hasil kacang tanah dan populasi gulma. J. Ilmu Pertanian Indonesia. 1:16-22.

Wahyudin, A., Y. Yuwariah, F.Y. Wicaksono, R.A.G. Bajri. 2017. Respons jagung (Zea mays L.) akibat jarak tanam pada sistem tanam legowo (2:1) dan berbagai dosis pupuk nitrogen pada tanah inceptisol Jatinangor. J. Kultivasi 16:507-513.

Wentasari, R., A.R.Gusta. 2018. Karakteristik iklim mikro serta pertumbuhan pada beberapa sistem tanam jagung dengan pola tanam tumpang sari dan tanam tunggal. J. Penelit. Pertan. Terap. 18:199-206.

Wentasari, R., R.N.Sesanti. 2016. Karakteristik iklim mikro dan produksi jagung manis pada beberapa sistem tanam. J. Penelit. Pertan. Terap. 16:94-100. 